\title{
Salmonella spp: IDENTIFIKASINYA PADA TELUR AYAM DI KABUPATEN PRINGSEWU PROVINSI LAMPUNG
}

\author{
Yessy Velina ${ }^{1 *}$, Haris Budiman ${ }^{2}$, Langen Puspitawati ${ }^{3}$ \\ ${ }^{1,2,3}$ Universitas Islam Negeri Raden Intan Lampung, Indonesia \\ Email: yessyvelina@radenintan.ac.id
}

Received: April 17 $7^{\text {th }}$ 2019. Accepted: June 26 ${ }^{\text {th }}, 2019$. Published: June $29^{\text {th }}, 2019$

\begin{abstract}
Eggs are one source of protein that contains complete nutrition and is in great demand by the community because the price is relatively affordable. Eggs can act as a good growth medium for microorganisms. Salmonella spp. is a bacterium that can infect eggs. These bacteria can cause Salmonellosis in humans in the form of typhoid fever, paratyphoid and non-typhoid or gastroenteritis. In the Indonesian National Standard (SNI) 7388:2009 stated that Salmonella spp. on fresh eggs is negative. The purpose of this study was to examine the presence or absence of Salmonella spp. found in chicken eggs produced in the village of Tegal Sari Gading Rejo District, Pringsewu District, Lampung Province. The research method used was descriptive method, by testing Salmonella culture using XLDA and HEA media. Nine egg samples were identified by purposive sampling technique, which is a technique with three criteria namely cracked, clean and dirty eggs, which is taken in laboratorium. Egg examination is carried out in the Veterinary Public Health laboratory of Lampung Veterinary Hall. The results showed that the nine samples were negative for Salmonella spp. thus there is no content of Salmonella spp. on chicken eggs sold on three farms in the village of Tegal Sari Gading Rejo Subdistrict, Pringsewu District, Lampung Province and the eggs were declared free of Salmonella spp.
\end{abstract}

Keywords: Salmonela spp. Salmonellosis, egg, tifoid

\begin{abstract}
Abstrak
Telur merupakan salah satu sumber protein yang mengandung gizi yang lengkap dan banyak diminati oleh masyarakat karena harganya yang relative terjangkau. Telur dapat berperan sebagai media pertumbuhan yang baik bagi mikroorganisme. Salmonella spp. Merupakan bakteri yang dapat menginfeksi telur. Bakteri ini dapat menyebabkan penyakit Salmonellosis pada manusia berupa demam tifoid, paratifoid dannon-tifoidataugastroentritis. Dalam Standar Nasional Indonesia (SNI) 7388: 2009 menyatakan bahwa Salmonella spp. pada telur segar adalah negatif. Tujuan penelitian ini adalah untuk memeriksa ada atau tidaknya bakteri Salmonella spp. yang terdapat pada telur ayam yang diproduksi di desa Tegal Sari Kecamatan Gading Rejo Kabupaten Pringsewu Provinsi Lampung. Metode penelitian yang digunakan adalah metode dekriptif, dengan uji kultur Salmonella menggunakan media XLDA dan HEA. Sembilan sampel telur yang diidentifikasi dengan teknik pengambilan sampel secara purposive sampling, yaitu suatu teknik dengan tiga kriteria yaitu telur yang retak, bersih dan kotor, yang diambli dari hasil uji laboratorium Pemeriksaan telur dilakukan di laboratorium Kesehatan Masyarakat Veteriner Balai Veteriner Lampung. Hasil penelitian menunjukkan bahwa Sembilan sampel tersebut dinyatakan negatif Salmonella spp. Dengan demikian tidak terdapat kandungan Salmonella spp. pada telur ayam yang dijual ditiga peternakan yang berada didesa Tegal Sari Kecamatan Gading Rejo Kabupaten Pringsewu Provinsi Lampung dan telur tersebut dinyatakan bebas Salmonella spp.
\end{abstract}

Kata Kunci: Salmonela spp. Salmonellosis, Telur, tifoid 


\section{PENDAHULUAN}

Telur merupakan salah satu sumber protein hewani yang sangat dibutuhkan oleh tubuh, dan mengandung asam amino esensial yang lengkap (Suryani, 2015). Salah satu keunggulan protein telur dibandingkan dengan protein hewani lainnya adalah daya cernanya yang sangat tinggi. Artinya, setiap gram protein yang masuk akan dicerna di dalam tubuh secara sempurna. Protein merupakan komponen penting dari makanan manusia yang dibutuhkan untuk pengganti jaringan, pasokan energi dan makromolekul serbaguna di sistem kehidupan yang mempunyai fungsi penting dalam semua proses biologi seperti sebagai katalis, transportasi, berbagai molekul lain seperti oksigen, sebagai kekebalan tubuh dan menghantarkan impuls saraf (Fredrick, Kumar, \& Ravichandran, 2013). Kekurangan protein penyebab retardasi pertumbuhan, pengecilan otot, edema dan penumpukan cairan dalam tubuh anak-anak (Bashir, Ossai, Shittu, Abubakar, \& Caleb, 2015). Telur merupakan salah satu pangan asal hewan yang mempunyai kandungan gizi yang baik. Oleh karena itu, konsumen harus memperhatikan kualitas serta kelayakan telur yang akan dikonsumsi sehingga terbebas dari berbagai macam bentuk kerusakan maupun terbebas dari bibit penyakit yang merugikan kesehatan manusia.

Banyak orang yang belum mengetahui bahwa mengkonsumsi telur mentah, makanan yang mengandung telur mentah, serta makanan yang mengandung telur yang dimasak kurang sempurna dan setengah matang dapat menyebabkan wabah salmonellosis, yaitu penyakit yang disebabkan oleh Salmonella spp. (Duguid \& North, 1991). Salmonella merupakan salah satu bakteri patogen terpenting di Eropa dansebagai sumber infeksi utama pada manusia yang mengkonsumsi daging babi. Kasusdi Amerika dan Eropa di laporkan bahwa terjadi infeksi karena Salmonella berkaitan dengan konsumsi telur dan produknya yang dimasak kurang sempurna. Selain ditemukan pada unggas dan produknya. Salmonella juga dapat ditemukan padadaging babi, daging sapi, susu dan produknya. Studi yang dilakukan di China menunjukkan adanya Salmonella pada daging yang dijual di pasar (Yang et al., 2010). Salmonella spp. adalah kelompok bakteri Gram negatif berbentuk batang dantidak berspora.

Bakteri ini memiliki sifat parasit yang menyebabkan reaksiperadangan tractus intestinal pada manuia dan hewan. Bakteri ini ditemukan padatahun 1880 pada penderita demam tifoid oleh Eberth dan dibenarkan oleh Robert Koch dalam budidaya bakteri pada tahun 1881. Salmonella spp. digolongkan dalam bakteri patogenik yang menjadi penyebab foodborne disease yang disebut Salmonellosis. Bakteri ini dapat tumbuh dan menyebabkan kerusakan pada jaringansel epitel usus. Gejala yang ditimbulkan berupa gastoenteritis, diare, sakit perut,demam atau tanpa demam, septikemia dan infeksi total (Ariyanti, 2005). Di laboratorium,Salmonella spp. dapat tumbuh pada suhu $5-47^{\circ} \mathrm{C}$ dan optimum pada suhu 35-37 ${ }^{\circ} \mathrm{C} . \mathrm{pH}$ pertumbuhan sekitar 4.0-9.0 dengan $\mathrm{pH}$ optimum 6.5-7.5 (Khaq \& Dewi, 2016). Salmonella spp dapat masuk kedalam telur malalui pori-pori kerabang atau ayam induk yang terinfeksi. Gejala yang ditimbulkan salmonellosis seperti sakit perut yang mendadak dengan diare encer atau berair, mual dan muntah, disertai demam dengan suhu 38 sampai $39^{\circ} \mathrm{C}$ (Pelczar, Chan, \& Hadioetomo, 1988). Cemaran Salmonella spp. pada telur dapat berasal dari kotoran ayam dan kloaka atau dalam kandang. Infeksi Salmonella spp. tersebut dapat menimbulkan wabah penyakit misalnya tifus oleh Salmonella typhyi, paratifus oleh Salmonella paratyphyi (Afifah, 2014). Selain penyakit tifus dan paratifus genus Salmonella pada usus manusia, binatang dan unggas. Makanan (telur dan daging) dapat tercemar oleh kuman ini dapat menyebabkan demam enterik, gastroenterik dan septikemia (Gupte \& Julius, 1990). 
Penelitian tentang bakteri yang terdapat pada telur sudah pernah dilakukan di beberapa Kabupaten dan Kota seperti di Sleman Yogyakarta (Nugroho, 2006) di Bali (Dewi, Nurlatifah, Widdhiasmoro, Riti, \& Purnawati, n.d.) dan Kota Kendari (Darmayani, Rosanty, \& Vanduwinata, 2017). Hasil dari beberapa sampel telur positif sebesar 1,4\% mengandung Salmonella sp. pada penelitian yang dilakukan di Kabupaten Sleman Yogyakarta. Penelitian analisis deskriptif kualitatif menggunakan metode pengambilan sampel secara purposive sampling pada media Xylose Lysine Deoxycholate Agar (XLDA), Hektoen Enteric Agar (HEA) dan Bismuth Sulfite Agar (BSA) menunjukkan hasil (0,65\%) positif pada sampel daging yang diambil di pasar tradisional. Sedangkan pengujian pada sampel telur menunjukkan hasil $100 \%$ negatif, pada sampel telur ayam yang diambil di peternakan (farm) di wilayah Bali, NTB dan NTT. Penelitian yang dilakukan (Darmayani,dkk 2017 ) yang menggunakan media agar Salmonella Shigella Agar (SSA) menunjukkan hasil negatif pada 34 sampel yang di peroleh dari pasar Kota Kendari. Oleh karena itu, penelitian ini memiliki kebaruan yaitu penelitian pada produksi telur di desa Tegal Sari kabupaten Pringsewu dengan uji kultur Salmonella menggunakan media XLDA dan HEA.

Provinsi Lampung khususnya di Kabupaten Pringsewu memiliki prospek potensial untuk mengembangkan ternak ayam ras petelur, karena kebutuhan masyarakat akan telur ayam cukup tinggi. Populasi ternak ayam ras petelur menurut Dinas Peternakan Kabupaten Pringsewu tahun 2016 sampai 2017. Tujuan penelitian ini yaitu untuk mengetahui apakah terdapat Salmonella spp.dan berapa sampel yang positif mengandung Salmonella spp.pada telur ayam petelur dari tiga peternakan ayam didesa Tegal Sari KecamatanGading Rejo Kabupaten Pringsewu.

\section{METODE PENELITIAN}

Penelitian ini menggunakan analisis data kualitatif deskriptif, selanjutnya ditampilkan dalam bentuk gambar atau foto dan uraian deskripsi. Penelitian ini menggunakan teknik pengumpulan data observasi. Hal-hal yang dilakukan yaitu; mengetahui dan menganalisis Salmonella spp. pada sampel telur ayam petelur yang berasal dari tiga peternakan Mulawarman, Surono dan Dendi didesa Tegal Sari Kecamatan Gading Rejo Kabupaten Pringsewu.

Alat yang digunakan dalam penelitian ini adalah cawan petri, pisau, tabung reaksi, tabung serologi ukuran 10x75 mm, spuit steril $10 \mathrm{ml}$, botol media, pinset, jarum inokulasi (ose), stomacher, pembakar bunsen, stirer, pengocok tabung (vortex), inkubator, penangas air, autoklaf, lemari steril (clean bench) dan lemari pendingin (refrigerator). Bahan yang digunakan dalam penelitian ini adalah sembilan sampel telur ayam, Lactose Broth (LB), Rappaport Vassiliadis (RV), Xylose Lysine Deoxycholate Agar (XLDA), Hektoen Entero Agar (HEA), Triple Sugar Iron Agar (TSIA), Lysine Iron Agar (LIA), Methyl Red Voges Proskauer (MR-VP), Simmon's Citrate Agar (SCA), Reagen Konvac, garam fisiologis (Nacl 0,85\%), isolat salmonella dan Salmonella Polyvalent Somatic (O).

Pengambilan sampel telur secara purposive sampling, yaitu teknik pengambilan sampel didasarkan pada suatu kriteria tertentu yang dibuat oleh peneliti sendiri. Telur diambil dari tiga peternakan yang berada di desa Tegal Sari Kecamatan Gading Rejo Kabupaten Pringsewu Provinsi Lampung dengan jumlah sampel telur yang diambil dari ketiga peternakan sebanyak 36 butir telur dengan tiga kriteria retak, bersih dan kotor. Setiap sampel telur diambil 4 butir telur dan diberi kode dengan menggunakan spidol untuk setiap butir. Telur-telur yang telah dikode diletakkan didalam tray dengan posisi bagian ujung 
runcing di atas dan dikemas baik agar tidak mudah pecah selama proses transportasi. Setelah itu, sampel telur dibawa untuk dilakukan tahap pengujian di laboratorium.

Tahapan pelaksanaan dalam penelitian dilaboratorium yaitu meliputi preparasi dimana Kerabang telur ayam dibersihkan dengan kapas alkohol, lalu di bagian ujung kerabang dipecahkan menggunakan pisau steril dan dibuang kulitnya secara hati-hati. Selanjutnya mengambil sebanyak $1 \mathrm{ml}$ kuning telur menggunakan spuit steril, dimasukan kedalam plastik steril lalu diberi kode. Tahapan selanjutnya adalah Pra-pengayaan yaitu menambahkan $1 \mathrm{ml}$ kuning telur ke dalam $9 \mathrm{ml}$ larutan LB dalam wadah steril yang berisi sampel telur, lalu dihomogenkan dengan stomacher selama 1 sampai 2 menit. Kemudian memindahkan suspensi ke dalam erlenmeyer dan diinkubasikan pada suhu $35^{\circ} \mathrm{C}$ selama 18 sampai 24 jam. Sedangkan tahapan ketiga adalah pengayaan yaitu dilakukan pengaduk perlahan biakan pra-pengayaan kemudian mengambil dan memindahkan masing-masing $0,1 \mathrm{ml}$ ke dalam $10 \mathrm{ml}$ media RV. Selanjutnya mediaRV diinkubasikan pada suhu $42^{\circ} \mathrm{C}$ selama 18 sampai 24 jam.

Pada tahapan keempat yaitu Isolasi dan Identifikasi dengan mengambil dua atau lebih koloni dengan jarum ose dari masing-masing media pengayaan yang telah diinkubasikan dan inokulasi pada media HEA dan XLDA. Selanjutnya media HEA dan XLDA diinkubasikan pada suhu $35^{\circ} \mathrm{C}$ selama 18 sampai 24 jam. Langkah selanjutnya mengamati koloni Salmonella spp. pada media HEA terlihat koloni berwarna hijau kebiruan dengan atau tanpa titik hitam (H2S). Pada media XLDA koloni terlihat merah muda dengan atau tanpa titik hitam mengkilat atau terlihat hampir seluruh koloni hitam. Lalu melakukan identifikasi dengan mengambil koloni yang diduga dari kedua media tersebut. Kemudian diinokulasi ke TSIA dan LIA dengan cara menusuk ke dasar media agar, selanjutnya digores pada media agar miring. Selanjutnya diinkubasikan pada suhu $35^{\circ} \mathrm{C}$ selama 18 sampai 24 jam. Mengamati koloni spesifik Salmonellas pp. dapat terlihat pada tabel berikut :

Tabel 1. Hasil Uji Salmonella spp. pada TSIAdan LIA (Veteriner, 2015)

\begin{tabular}{|c|c|c|c|}
\hline $\begin{array}{l}\text { Media Agar } \\
\text { Miring (slant) }\end{array}$ & $\begin{array}{c}\text { Dasar Agar } \\
\text { (Buttom) }\end{array}$ & H2S & Gas \\
\hline TSIA & Alkalin /K merah & Asam/A (kuning) & $\begin{array}{l}\text { Positif (hitam) } \\
\text { Negatif/Positif }\end{array}$ \\
\hline LIA & Alkalin /K ungu & Alkalin /K ungu & $\begin{array}{l}\text { Positif (hitam) } \\
\text { Negatif/Positif }\end{array}$ \\
\hline
\end{tabular}

Tahapan terakhir merupakan uji biokimia yang dilakukan dalam penelitian ini yang meliputi uji Indol, yaitu menginokulasi koloni media TSIA dan TB lalu diinkubasikan menginkubasi pada suhu $35^{\circ} \mathrm{C}$ selama 18 sampai 24 jam. Menambahkan 0,2 sampai dengan $0,3 \mathrm{ml}$ Reagen Konvacs. Selanjutnya hasil uji positif ditandai dengan adanya cincin merah dipermukaan media. Sedangkan hasil negatif tidak ditandai dengan adanya cincin merah dipermukaan media (larutan berbentuk kuning). Uji berikutnya adalah uji Methly-Red (MR) yaitu dengan mengambil biakan dari media TSIA dengan ose diinokulasikan ke dalam tabung yang berisi $10 \mathrm{ml}$ media MR-VP dan diinkubasikan selama $35^{\circ} \mathrm{C}$ selama 48 jam. Selanjutnya menambahkan 5 tetes sampai dengan 6 tetes indikator Methly Red pada tabung. Hasil uji positif ditandai dengan adanya difusi warna merah ke dalam media. Sedangkan hasil uji negatif Salmonella spp. ditandai dengan terjadinya warna kuning pada media. Uji MR umumnya memberikan hasil positif Salmonella spp. 
Uji kimia yang ketiga yaitu menggunakan uji Voges-Proskauer (VP) yaitu dengan mengambil biakan dari media TSIA dengan ose lalu diinokulasikan ke dalam tabung yang berisi $10 \mathrm{ml}$ media MR-VP dan diinkubasikan selama $35^{\circ} \mathrm{C}$ selama 18 sampai 24 jam. Kemudian memindahkan $5 \mathrm{ml} \mathrm{MR}-\mathrm{VP}$ ke dalam tabung dan menambahkan 0,6 ml larutan $\alpha$-naphthol dan $0,2 \mathrm{ml} \mathrm{KOH} 40 \%$, kemudian digoyang-goyang sampai tercampur dan didiamkan. Hasil uji positif Salmonella spp. apabila terjadi perubahan warna pink sampai merah delima. Sedangkan hasil uji negatif Salmonella spp. tidak terjadi perubahan warna pada media. Uji yang keempat dari uji kimia adalah menggunakan uji Simmons Citrate Agar (SCA). Uji ini merupakan menginokulasikan koloni TSIA ke dalam SCA dengan ose. Kemudian diinkubasikan pada suhu $35^{\circ} \mathrm{C}$ selama 48 jam. Hasil uji positif ditandai dengan adanya pertumbuhan koloni yang diikuti perubahan warna hijau menjadi biru. Sedangkan uji negatif ditandai dengan tidak adanya pertumbuhan koloni atau tumbuh sangat sedikit dan tidak terjadi perubahan warna. Uji SCA memberikan hasil positif Salmonella spp.

Uji kimia yang terakhir merupakan uji Serologis (Uji Polyvalent Somatic O) dimana dilakukan peletakan satu ose koloni dari TSIA atau LIA pada gelas preparat dan menambahkan satu tetes larutan garam fisiologis (Nacl 0,85\%) steril dan meratakan dengan kultur. Menambahkan satu tetes salmonella polyvalent somatic (O) antiserum disamping suspensi koloni. Mencampurkan suspensi koloni ke antiserum sampai tercampur sempurna. Memiringkan campuran tersebut ke kiri dan kanan dengan latar belakang gelap lalu mengamati adanya reaksi aglutinasi. Menyiapkan kontrol dengan mencampur larutan garam fisiologis dan antiserum. Melakukan uji somatik (O) grup monovalent antisera Vi seperti uji polyvalent.

\section{HASIL PENELITIAN DAN PEMBAHASAN}

Tabel 2. Hasil Pengamatan Uji Biokimia Dan Uji Serologis

\begin{tabular}{|c|c|c|c|c|c|c|c|c|c|}
\hline \multirow[b]{2}{*}{ No } & \multirow{2}{*}{$\begin{array}{c}\text { Kode } \\
\text { Sampel }\end{array}$} & \multicolumn{8}{|c|}{ Uji Substrat } \\
\hline & & TSIA & LIA & MR & VP & Indol & SCA & $\begin{array}{l}\text { Polyvalent } \\
\text { Somatic } O\end{array}$ & $\begin{array}{c}\text { Salmonella } \\
\text { spp. }\end{array}$ \\
\hline 1 & M1 & - & - & - & - & - & - & - & - \\
\hline 2 & M2 & - & - & - & - & - & - & - & - \\
\hline 3 & M3 & - & - & - & - & - & - & - & - \\
\hline 4 & $\mathrm{~S} 1$ & - & - & - & - & - & - & - & - \\
\hline 5 & $\mathrm{~S} 2$ & - & - & - & - & - & - & - & - \\
\hline 6 & S3 & - & - & - & - & - & - & - & - \\
\hline 7 & D1 & - & - & - & - & - & - & - & - \\
\hline 8 & D2 & - & - & - & - & - & - & - & - \\
\hline 9 & D3 & - & - & - & - & - & - & - & - \\
\hline 10 & $\mathrm{~K}+$ & + & + & + & + & + & + & + & + \\
\hline
\end{tabular}

Keterangan : $\quad(+)$ Indikasi adanya Salmonella spp.

(-) Indikasi tidak adanya Salmonella spp.

Berdasarkan Tabel 2 di atas merupakan hasil pengamatan uji biokimia dan uji serologis pada sampel 4 yang diduga terdapat pertumbuhan koloni Salmonella spp. dilanjutkan pengujian biokimia diantaranya, TSIA, LIA, Indol, MR, VP, SCA danPolyvalent Somatic O, diperoleh hasil negatif artinya koloni tersebut bukan termasuk Salmonella spp. karena Salmonella adalah salah satu spesies bakteri yang termasuk dalam 
anggota famili Enterobacteriaceae. Habitat utamanya berada dalam saluran pencernaan hewandan manusia (Portillo, 2000) Salmonella spp. biasanya ditemukan pada bahan pangan yang mengandung protein tinggi. Protein merupakan salah satu zat yang baik bagi pertumbuhan mikroorganisme. Keadaan tertentu atau dalam jumlah yang melebihi batas, bakteri dapat menyebabkan gangguan kesehatan bagi yang mengkonsumsinya. Salmonellosis, merupakan penyakit yang disebabkan oleh Salmonella dengan gejala seperti mual-mual, muntah, sakit perut, sakit kepala, kedinginan, demam dan diare. Bakteri ini dapat mengkontaminasi telur sewaktu masih dalam indung telur ayam, tetapi yang paling sering terjadi adalah setelah telur dikeluarkan, terutama apabila kebersihan kandang dan lingkungan kurang diperhatikan (Afifah, 2014).

Salmonella dikenal sebagai agen zoonosis dan merupakan peringkat kelima dalam zoonosis prioritas, sesuai Keputusan Mentri Pertanian nomor 4971/2012 tentang zoonosis prioritas (Dewi et al., n.d.). Salah satu surveilens dari penyakit zoonosis adalah makanan yang bersumber dari pangan asal hewan yaitu telur yang terdapat pada peternakan. Sampel telur yang diambil difokuskan pada telur-telur yang baru dikeluarkan dari kloaka dengan berbagai jenis umur, sehingga pengambilan sampel langsung dari tempat penyimpanan telur. Surveilens ini dilakukan untuk melihat sejauh mana tingkat pencemaran salmonellosis dipeternakan terjadi, baik dari segi pemeliharaan, pakan maupun sanitasi kandang dan lingkungan. Mengenai perkembangan populasi ternak Kabupaten Pringsewu tahun 2017 menyebutkan bahwa Kecamatan Gading Rejo, merupakan salah satu kecamatan yang mempunyai populasi dari tahun 2016 sebanyak 288,00 ekor dan mengalami kenaikan yang pesat pada tahun 2017 sebanyak 360,600 ekor. Penyebaran populasi ternak ayam petelur terbanyak berada di kecamatan ini adalah desa Tegal Sari.

Produksi telur yang dihasilkan dari peternak rakyat tersebut didistribusikan ke berbagai wilayah Kabupaten/Kota yang berada di Provinsi Lampung. Hal ini dapat memenuhi kebutuhan gizi yang lengkap serta memiliki harga yang relatif terjangkau dibandingkan dengan protein hewani lainnya. Oleh karena itu peneliti menjadikan desa Tegal Sari sebagai objek penelitian. Peternakan ayam petelur yang disurvey adalah peternakan dengan jumlah populasi di atas 1000 ekor dengan berbagai tingkatan umur, yaitu umur muda yang baru belajar bertelur, umur subur yaitu yang lagi banyak produksi telurnya serta umur tua dengan produksi telur yang sudah menurun. Menurut Chusniati, Sri, dkk (2006) menyatakan bahwa ada dua kemungkinan cara masuknya Salmonella spp. kedalam telur, yaitu secara langsung (vertikal), melalui kuning telur dan putih telur dari ovarium induk ayam yang terinfeksi Salmonella spp., masuknya Salmonella spp. juga bisa secara horizontal, melalui poripori pada kulit telur.

Cemaran bakteri salmonella spp. dapat terjadi melalui secara vertikal atau yang disebut dengan transovarial adalah cemaran pada telur yang berasal dari induk ayam ayam yang terinfeksi. Cemaran pada induk petelur diawali dengan tertelannya bakteri melalui pakan atau air minum yang tercemar seperti debu, tanah dan tinja. Bakteri tersebut selanjutnya masuk dan memperbanyak diri dalam saluran pencernaan maupun peritonium. Selanjutnya akan menembus dinding usus sehingga menimbulkan reaksi inflamasi. Bakteri tersebut dapat hidup dalam makrofag yang terdapat dalam saluran pencernaan. Selanjutnya menembus mukosa, masuk kedalam sistem limfatik dan dapat mencapai saluran darah sehingga dapat menyebabkan bakterimia atau abses. Bakteri tersebut akan menyebar ke organ lain seperti organ reproduksi ovarium (Chusm'ati, Budiono, \& Kumijasanfi, n.d.). Penularan Salmonella spp. pada telur dapat terjadi secara horizontal, yaitu dengan cara Salmonella spp memperbanyak diri dalam saluran pencernaan selanjutnya akan diekskresikan melalui feses dan menyebabkan penularan bakteri dengan cara menempel pada permukaan kerabang telur (Thiagarajan, Saeed, \& Asem, 1994). Infeksi Salmonella 
spp. juga dapat terjadi akibat ternak ayam yang mengkonsumsi pakan yang tercemar Salmonella spp., ataupun karena telur tersebut mengalami keretakan atau kepecahan yang disebabkan karena kemiringan kandang, pengumpulan dan pengepakkan yang salah (Supartika, Wirata, \& Uliantara, 2015).

Pengujian yang dilakukan oleh peneliti menggunakan 9 sampel yang memiliki kriteria seperti retak, bersih dan kotor. Kriteria tersebut dibuat oleh peneliti terkait ada tidaknya Salmonella spp. pada telur ayam ras yang diproduksi oleh ketiga peternakan tersebut. Setelah dilakukan pengujian terhadap 9 sampel yang dilakukan sebanyak dua kali pengambilan sampel dikandang. Sampel 4 merupakan sampel pada telur yang retak, sampel tersebut terdapat pertumbuhan koloni yang diduga Salmonella spp. Perbedaan morfologi yang terlihat pada sampel 4 yang ditanam di media XLDA dan HEA serta morfologi yang terlihat pada kontrol positif di media XLDA dan HEA. Tahapan selanjutnya yaitu menguji sampel 4 melalui biokimia dan uji serologis menggunakan polyvalent somatic O. Hasil yang diperoleh adalah negatif seperti yang tampak pada Tabel di atas, tidak mengandung Salmonella spp. pada sampel 4 (telur yang retak).

Tidak adanya Salmonella spp. pada sampel 4, karena telur memiliki pertahanan alamiah berupa pertahanan fisik yang terdapat pada kerabang telur. Kerabang telur (shell) terdapat beberapa ribu pori-pori (7.000-17.000) per butir yang digunakan untuk pertukaran gas. Pori-pori tersebut berukuran sempit, berukuran 0,01-0,07 $\mathrm{mm}$ dan tersebar diseluruh permukaan kerabang telur. Telur yang masih baru, poriporinya masih dilapisi oleh lapisan tipis kutikula yang terdiri dari $90 \%$ protein dan sedikit lemak. Fungsi kutikula untuk mencegah penetrasi mikroba melalui kerabang telur dan mengurangi penguapan air yang terlalu cepat. Pertahanan fisik pada telur juga terdapat pada selaput, pada bagian kerabang telur ditemukan dua selaput (membran), yaitu membran kerabang telur (outer shell membrane) dan membran putih telur (inner shell membrane) yang berfungsi melindungi isi telur dari infiltrasi bakteri dari luar (Supartika et al., 2015). Selain pertahanan fisik, telur memiliki pertahanan secara kimiawi yang terletak pada putih telur yaitu lisozim. Lisozim merupakan suatu zat bakterisida yang mampu menghancurkan bakteri (Arisman \& Kes, 2009). Putih telur juga mengandung ovotransferin yang berfungsi menghambat pertumbuhan mikroorganisme karena daya khelasi yang dimiliki terutama terhadap ion $\mathrm{Fe}++$ (Arisman \& Kes, 2009).

Penelitian di atas, sejalan dengan penelitian terdahulu, diantaranya Hasil penelitian lain bahwa menggunakan medium selektif Salmonella Shigella Agar (SSA) dari 34 telur yang di jual di pasar Kota Kendari provinsi Sulawesi Tenggara menunjukkan hasil negatif (Fajar, Fakhrurrazi, \& Razali, 2018). Dalam penelitian lain yang melakukan pengambilan sampel daging ayam di pasar tradisional dan sampel telur ayam di peternakan (Farm) di wilayah provinsi Bali, NTB dan NTT sebanyak 155 sampel daging ayam dan 150 sampel telur menggunakan media agar Hektoen Enteric Agar (HEA), Xylose Lysine Deoxycholate Agar (XLDA) dan Bismuth Sulfite Agar (BSA), hasil uji menunjukkan bahwa positif satu sampel daging ayam $(0,65 \%)$ positif mengandung Salmonella sp. sedangkan semua sampel telur $100 \%$ negatif Salmonella sp.(Supartika et al., 2015).

Pengendalian dan penanganan cemaran bakteri Salmonella spp. sudah dilakukan secara sinergis oleh pihak peternak tersebut dengan Dinas Peternakan setempat khusunya dalam hal ini Puskeswan yang berada di Kecamatan, mengenai kebersihan kandang, biosekueriti serta kesehatan bagi hewan ternak agar meminimalisir infeksi Salmonella spp. pada ayam petelur. Selanjutnya proses antisipasi yang dapat dilakukan oleh masyarakat dalam membeli telur ialah memperhatikan kondisi fisik, seperti warna kerabang telur atau rusaknya telur. Selain itu, bahwa pemilihan telur yang baik terdapat beberapa ciri-ciri antara lain kulit bersih, halus, berwarna mulus, rongga kantong udara kecil, kuning telurnya 
terletak ditengah dan tidak bergerak, putih telur bagian dalam kental dan tinggi, pada bagian putih telur maupun kuning telur tidak terdapat noda darah maupun daging. Bentuk serta besarnya juga proposional dan normal (ARAB \& SAYUDIN, n.d.).

Berdasarkan data di atas yang telah dilakukan pengujian pada sampel 4 yang diduga terdapat pertumbuhan koloni Salmonella spp., yang telah diuji biokimia dan serologis, diperoleh hasil negatif Salmonella spp. sehingga dapat disimpulkan bahwa telur yang di produksi oleh peternakan tersebut bebas Salmonella spp. oleh karena itu hasil yang didapat adalah negatif Salmonella spp. Oleh karena itu, penelitian ini sesuai dengan syarat yang dituangkan oleh pemerintah terkait batas maksimum cemaran mikroba (BMCM) SNI 7388 : 2009 (Nasional, 2009).

\section{SIMPULAN DAN SARAN}

Berdasarkan hasil penelitian tentang identifikasi Salmonella spp. pada telur yang berasal dari tiga peternakan di desa Tegal Sari Kecamatan Gading Rejo Kabupaten Pringsewu menggunakan uji kultur Salmonella spp. menurut SNI 2897 : 2008 dan Kesmavet (validasi metode uji di Balai Veteriner Lampung 2017), tidak ditemukan adanya Salmonella spp. pada sembilan sampel telur. Dengan demikian telur yang berasal dari tiga peternakan tersebut dinyatakan bebas Salmonella spp.

Berdasarkan penelitian yang dilakukan maka disarankan untuk melakukan penelitian dengan menggunakan sampel yang lebih banyak dan menggunakan alat uji yang lebih modern untuk mendapatkan kevalidan yang tinggi guna mengidentifikasi bakteri Shigella.

\section{DAFTAR PUSTAKA}

Afifah, N. (2014). Uji salmonella-shigella pada telur ayam yang disimpan pada suhu dan waktu yang berbeda. Edu Research, 2(1), 35-46.

ARAB, W. K. T. A., \& SAYUDIN, M. (n.d.). Penggunaan Ramuan Herbal Dan Tepung Daun Murbei Terhadap Berat Telur, Tebal Kerabang Dan.

Arisman, M. B., \& Kes, M. (2009). Keracunan Makanan Buku Ajar Ilmu Gizi. EGC.

Ariyanti, T. (2005). Food Safety of Animal Products That Viewed from Disease Aspect. WARTAZOA. Indonesian Bulletin of Animal and Veterinary Sciences, 15(4), 187205.

Bashir, L., Ossai, P. C., Shittu, O. K., Abubakar, A. N., \& Caleb, T. (2015). Comparison of the nutritional value of egg yolk and egg albumin from domestic chicken, guinea fowl and hybrid chicken. American Journal of Experimental Agriculture, 6(5), 310316.

Chusm'ati, S., Budiono, R. N., \& Kumijasanfi, R. (n.d.). CAMPURAN IAMU DI KECAMATAN SIDOARJO.

Darmayani, S., Rosanty, A., \& Vanduwinata, V. (2017). Identifikasi bakteri Salmonella sp. pada telur yang dijual di pasar Kota Kendari Provinsi Sulawesi Tenggara. Biogenesis: Jurnal Ilmiah Biologi, 5(1), 21-26. 
Dewi, A. A. S., Nurlatifah, I., Widdhiasmoro, N. P., Riti, N., \& Purnawati, D. (n.d.). Prevalensi Cemaran Mikroba Dan Residu Antibiotika Pada Pangan Asal Hewan (PAH) Di Provinsi Bali, Nusa Tenggara Barat Dan Nusa Tenggara Timur Tahun 2013.

Duguid, J. P., \& North, R. A. E. (1991). Eggs and Salmonella food-poisoning: an evaluation. Journal of Medical Microbiology, 34(2), 65-72.

Fajar, S. A., Fakhrurrazi, F., \& Razali, R. (2018). Isolasi Salmonella Sp Pada Telur Setengah Matang Yang Berasal Dari Warung Kopi Di Alue Naga Banda Aceh (The Isolation Of Salmonella Sp On Half-Cooked Egg From The Alue Naga Banda Aceh Coffe Shop). JURNAL ILMIAH MAHASISWA VETERINER, 2(3), 276-282.

Fredrick, W. S., Kumar, V. S., \& Ravichandran, S. (2013). Protein analysis of the crab haemolymph collected from the trash. International Journal of Pharmacy and Pharmaceutical Sciences, 5(4), 304-308.

Gupte, S., \& Julius, P. (1990). Mikrobiologi dasar. Jakarta: Binarupa Aksara.

Khaq, K. N., \& Dewi, L. (2016). Deteksi Cemaran Bakteri Koliform Dan Salmonella sp. pada Tempe yang Dikemas Daun Pisang di Daerah Salatiga. Agric, 28(1), 79-86.

Nasional, B. S. (2009). Batas maksimum cemaran mikroba dalam pangan. SNI, 7388(2009), 67.220 .

Nugroho, W. S. (2006). Analisis Tingkat Cemaran Salmonella dan Faktor-faktor Pencemaran pada Telur Ayam Ras di Kabupaten Sleman Yogyakarta. J. Veteriner, 7, 47-53.

Pelczar, M. J., Chan, E. C. S., \& Hadioetomo, R. S. (1988). Dasar-dasar mikrobiologi. Universitas Indonesia.

Portillo, F. G. (2000). Molecular and cellular biology of Salmonella pathogenesis in microbial foodborne disease: Mechanisms of pathogenesis and toxin synthesis. Technomic Publishing Company., Inc, 851, 3-7.

Supartika, I. K. E., Wirata, I. K., \& Uliantara, I. G. A. J. (2015). Surveilans Penyakit Gangguan Reproduksi di Wilayah Kerja (Provinsi Bali, Nusa Tenggara Barat Dan Nusa Tenggara Timur) Tahun 2015. LAPORAN TEKNIS, 109.

Suryani, R. (2015). Beternak puyuh di pekarangan tanpa bau. Cetakan I. Arcitra. Yogyakarta.

Thiagarajan, D., Saeed, A. M., \& Asem, E. K. (1994). Mechanism of transovarian transmission of Salmonella enteritidis in laying hens. Poultry Science, 73(1), 89-98.

Veteriner, B. (2015). Buku Pedoman Metode Uji Cemaran Mikroba dan Batas Maksimum dalam Daging, Telur dan Susu. Balai Veteriner Lampung. Bandar Lampung.

Yang, B., Qu, D., Zhang, X., Shen, J., Cui, S., Shi, Y., ... Meng, J. (2010). Prevalence and characterization of Salmonella serovars in retail meats of marketplace in Shaanxi, China. International Journal of Food Microbiology, 141(1-2), 63-72. 